Sulla, V., and Zikhali, P. (20I8). Overcoming poverty and inequality in South Africa: An assessment of drivers, constraints and opportunities. International Bank for Reconstruction and Development/The World Bank, Washington. Retrieved from http://documents.worldbank.org/ curated/en/53048I52I735906534/pdf/I2452I-REV-OUOSouth-AfricaPoverty-and-Inequality-Assessment-Report-2018-FINAL-WEB.pdf.

Swilling, M. (2016). Africa's game changers and the catalysts of social and system innovation. Ecology and Society 21(I), 37.

Taylor, J. B. (I970). Introducing social innovation. The Journal of Applied Behavioral Science 6(I), 69-77.

Tencer, D. (20I7). $85 \%$ of jobs that will exist in 2030 haven't been invented yet. In: Dell. Huff Post, I4 July.

Tomlinson, M. (20I7). Student perceptions of themselves as 'consumers' of higher education. British Journal of Sociology of Education 38(4), 450-467.

Tremblay, K., Lalancette, D., and Roseveare, D. (20I2). Assessment of higher education learning outcomes: Feasibility study report, volume 1 design and implementation. Paris, France: Organisation for Economic Co-operation and Development.

Van der Have, R. P., and Rubalcaba, L. (2016). Social innovation research: An emerging area of innovation studies? Research Policy 45(9), I923-I935.

Van Niekerk, A., and Viviers, W. (20I4). Promoting sustainable economic growth in South Africa through the export of low-carbon environmental goods. South African Journal of Economic and Management Sciences 17(4), 427-439.

Walker, B. H., and Salt, D. (2006). Resilience thinking: sustaining ecosystems and people in a changing world. Washington D.C.: Island Press.

Walwyn, D., and Cloete, L. (20I8). Draft White Paper on Science, Technology and Innovation neglects to prioritise issues of performance and human capability. South African Journal of Science 114(II-I2), I-6.

Windeløv-Lidzélius, C. (20I8). The School as a Living Lab - The Case of Kaospilot. In: M. Dezuanni, M. Foth, K.M. Mallan, H.E. Hughes and R. Osborne. Digital Participation through Social Living Labs, pp. 77-96. Elsevier.

Zweig, D., Fung, C., and Han, D. (2008). Redefining the brain drain: China's diaspora option. Science Technology and Society 13(I), I-33. https://doi.org/I0.II77\%2Fo97I72I8070I300I0I

\section{The Impact of Tertiary Students' Entry Characteristics and their Academic Performance}

\author{
Maame Afua Nkrumah
}

\section{Abstract}

This article examines the effect of tertiary students' entry characteristics on academic performance using the 'value added' approach and MET Polytechnic, Ghana as a case study. The input-process-output-context framework presented in the Global Monitoring Report (2005) by Scheerens was used to select appropriate variables for the study. The study focused on three generic courses - African Studies, Communicative Skills and Computer Literacy. Data from different sources, including secondary data and administrative records from the Polytechnic were analysed using multilevel analysis. The overall effect of the selected variables was mixed and outcomes specific. For example, English language impacted positively on African Studies but negatively on second semester Computer Literacy, while age and gender had a negative effect on first semester Computer Literacy. Although the findings may not directly benefit analogous institutions, several lessons, including the need to create appropriate institutional datasets for future comparisons across institutions can be learnt.

Key words: Age, gender, department context, previous achievement, SES, 'value added'.

Cet article examine l'effet des caractéristiques d'entrée des étudiants de l'enseignement supérieur sur les résultats scolaires en utilisant l'approche de la « valeur ajoutée » et le MET Polytechnic, au Ghana, comme étude de cas. Le cadre entrée-processus-sortie-contexte présenté dans le Rapport mondial de suivi (2005) par Scheerens a été utilisé pour sélectionner les variables appropriées pour l'étude. L'étude s'est concentrée sur trois cours génériques - études africaines, compétences communicatives et connaissances informatiques. Des données provenant de différentes sources, y compris les données secondaires et les dossiers administratifs de l'École

ABOUT THE AUthoR: MAAME AFUA NKRUMAH, Takoradi Technical University, Ghana. Email: manbristol@hotmail.com 
polytechnique, ont été analysées à l'aide d'analyses à plusieurs niveaux. L'effet global des variables sélectionnées était mitigé et les résultats étaient spécifiques aux institutions. Par exemple, la langue anglaise a eu un impact positif sur les études africaines, mais négatif sur les connaissances informatiques du deuxième semestre, tandis que l'âge et le sexe ont eu un effet négatif sur les connaissances informatiques du premier semestre. Les résultats pourraient ne pas profiter directement à des institutions analogues, mais plusieurs leçons, y compris la nécessité de créer des ensembles de données institutionnels appropriés pour les comparaisons futures entre les institutions, peuvent être tirées.

Mots clés: âge, sexe, contexte du département, réalisations antérieures, SSE, «valeur ajoutée »

\section{Introduction}

This article focuses on the effect of tertiary students' entry characteristics on academic performance using the 'value added' ('VA') approach and MET Polytechnic, Ghana as a case study.

The literature associates student performance with many factors, some directly associated with student characteristics and others with the context of teaching and learning and the classroom teacher (Chiao and Chiu, 2018; Erdogdu and Erdogdu, 2015; Kupermintz, 2003; Rutter and Maughan, 2002). More specifically, factors like students' gender, age, prior attainment, and peer group, etc. have been identified as affecting performance at the pre-tertiary level (Scheerens and Bosker, I997; Thomas and Mortimore, I996). At the tertiary level, students' entry characteristics, commitment, experiences after entry, academic and social integration, the nature of the institution (e.g., residential, size, disciplines, etc.) have been found to influence their performance (Evans, 2000; Kuh, 200I; Gardner, 2005; Mills et al., 2009). Additional factors include dominant norms and values, purposeful student-faculty contact, active and collaborative learning and clearly communicated high expectations (Kuh et al., 2006; Pascarella, 200I; Pascarella and Terenzini, 2005).

For the purpose of this study, four main groups of student entry characteristics were selected: (I) previous attainment (English, Maths and Science), (2) background (gender, age, local language spoken), (3) socio-economic status (SES) (place of residence and language spoken) and (4) department context in the form of the mean prior attainment. These variables were considered important due to their significant contribution to a better understanding of student success (Kuh et al., 2006; Yu and Thomas, 2008).
Prior achievement

Prior attainment has been identified as the single most important explanatory variable that explains students' academic achievement (Rodger, 2007; Bratti et al., 2004; Rodgers and Ghosh, 200I). This is due to the fact that knowledge and skills in areas relevant to the curriculum are required to serve as baseline knowledge to which subsequent progress or knowledge can be added (see Sammons, 2007; Thomas, 200I). The percentage of total variance in student achievement explained by prior attainment at the tertiary level is II-I2\% in the Pure and Applied Sciences and 7-8\% in the Social Sciences and the Arts (Johnes, 2006).

Background and socioeconomic status (gender and age)

Yu and Thomas (2008) examined the importance of a wide range of explanatory variables (e.g., pupil gender, age, SES) using a secondary dataset from I4 member countries of the Southern and Eastern Africa Consortium for Monitoring Educational Quality (SACMEQ) and multilevel modelling statistical techniques. The study found that students' gender, age and SES had little or no influence on performance. At the tertiary level, inclusion of these factors only explained $3 \%$ of the total variance, although it was statistically significant (Johnes, 2006; Hoskins et al., I997).

The study on which this article is based focused on Higher National Diploma (HND) students' performance (examination scores) in three generic courses - African Studies (AFS), Communication Skills (CS) and Computer Literacy (CL) for three academic years (2007/2008 to 2009/10). These courses were chosen because the overall purpose of this study was quality improvement. Knight (I996) identified five discrete but interrelated notions of quality in $\mathrm{HE}$, namely quality as exceptional, perfection, fitness for purpose, value for money and transformation. The notion of transformation adopted for this study involves enhancing and empowering students. Interestingly, this notion is also associated with the concept of VA because the HE sector is expected to add value to students by developing in them generic competencies, including oral communication, teamwork and interpersonal skills, self-management, problem solving and leadership skills to better prepare them for the world of work (Marginson, I993). The study thus examined how the institution was developing and empowering students in the three generic courses, Communicative Skills, Computer Literacy and African Studies.

The scores were for examinations conducted and marked under the supervision of the National Board for Professional and Technician Examinations (NABPTEX) that is responsible for all HND programmes in Ghana.

Unlike discipline specific courses for which examinations may not be comparable, examinations for these generic courses were common and compulsory for all first-year students, regardless of their field of study. 
Communication skills are necessary to negotiate and create new understanding, interact with others, and promote personal learning. Computer literacy is essential in an increasingly digital world, including teaching/ learning and training (Santos and Serpa, 20I7). African Studies aims to foster critical thinking and equip students with resources/tools/methods that enhance their understanding and appreciation of issues pertinent to African cultures, societies, and development.

Similar courses identified in the literature include research and inquiry, critical problem-solving skills, teamwork skills, continuous leaning and information management, entrepreneurship skills, professional ethics and moral and leadership skills (Muslim et al., 2012; Barrie, 2006). These courses are generally expected to facilitate the learning process by providing both form and function to disciplinary specific knowledge (Bowden, 2000; Barrie, 2006).

The VA approach that was employed differs from two other approaches that also rely on student test scores to predict their performance. The first uses the average test scores or pass rates while the second focuses on the rate of each school's improvement during the year (measured by changes in student test scores after say, a year relative to a specific target of improvement). The main drawback of these approaches is their failure to account for differences in the mix of students upon entry in terms of for example, previous achievement, background, SES, etc. (Ladd and Walsh, 2002).

The VA approach has mainly been used at the pre-tertiary level across different institutions. For instance, Thomas (200I) employed six datasets relating to different regions in the United Kingdom and abroad (Lancashire, London, Jersey, Scotland, the Netherlands and England) to examine the differences between schools. The study found that prior attainment alone accounted for $48 \%$ of the total variance among schools (see also, Jung Peng, 2006; Rumberger and Palardy, 2005; Sammons, Thomas and Mortimore 1997). Jung Peng et al. (2006) used the VA approach to illustrate how assessment data from a Chinese educational authority could be used to improve the quality of teaching and learning. The study highlighted the lack of evidence in China on the size and extent of school effects and the lack of teacher engagement in the use of such data to inform practice. Singh (20I3) used panel data to estimate VA models of learning production in private and government schools in Andhra Pradesh (India). The study showed that attending a private school had no effect on Mathematics; but a positive effect on English, and a mixed effect on Telugu (the official language of the Indian states of Andhra Pradesh and Telangana) for children aged 8-10 and I5. In urban areas, no effect was noted. However, teachers' absence, effort, and teaching practices, and class size significantly affected learning. As noted earlier, within the African context, the importance of a wide range of explanatory variables such as pupil gender, age, and socio-economic factors, etc. were investigated by $\mathrm{Yu}$ and Thomas (2008).

However, the VA approach has not been extensively used at the tertiary level within a single institution. It was employed in this study for a number of reasons.

Firstly, the variables usually examined at the pre-tertiary level are also common to tertiary education (e.g., prior attainment, student SES, background, etc.), Secondly, comparisons across different institutions may be problematic as their context and examinations even for the same courses may differ. For this reason, the study's findings are limited to departments within MET Polytechnic (this is considered as a pilot study until comparable data is available on other institutions). Thirdly, measuring VA has long been a goal of higher education (Rogers, 2007). For instance, Universities UK's review of the United Kingdom's White Paper on The Future of Higher Education stated: "We have asked HEFCE [Higher Education Funding Council for England] to review current methodologies for recording student achievement and to develop more sophisticated ways of measuring 'value added' - the distance travelled by the individual learner" (Teichler, 2003, p. 48).

The VA approach has also been used in further education. Armstrong and McVicar's (2000, p. 4) study on the performance of Northern Ireland's vocational education and training sector in terms of qualifications and value added outcomes concluded that, "it is necessary to account for initial conditions (i.e. qualifications and skills on entry along with socio-economic background characteristics) if we are to correctly monitor the contribution of the various routes and institutions involved in improving the skill levels of young people".

This approach is also preferred by many educational researchers due to its ability to capture institutions' progressive, positive influence on students' learning by measuring their pre- and post-attainment at different points in time (Rumberger and Palardy, 2004; Thomas, 200I; Rubenstein et al., 2003). It enables estimation of the contribution that factors within the control of schools (e.g., teachers, policies, context) make to student learning. The VA approach's complex statistical techniques also provide estimations of teacher and school effects free from distortions due to powerful non-educational factors such as the family (Koedel, Mihaly and Rockoff, 20I5; Tam, 200I).

The VA approach has only recently been employed to examine quality issues in African higher education. Furthermore, in other parts of the world, it has primarily been applied at pre-tertiary level. This study posited that, if its principles are carefully applied and replicated, it could be employed 
at tertiary level. The main objective was to gather empirical evidence in support of quality improvement within the framework of self-evaluation, given that quality initiatives emanating from institutions that focus on their unique context can enhance students' educational experience and promote and sustain quality over time (Houston, 2008; Tam, 200I). The study thus contributes to existing knowledge by presenting evidence from a 'new' context.

\section{Materials and methods}

A case study was considered appropriate as the research involved an indepth investigation of a single institution (Yin, 2009). However, this could mean that the findings may not be generalisable to other contexts. Nonetheless, the findings add to the body of knowledge in this field from a Ghanaian perspective.

The EFA Global Monitoring Report's (2005) input-process-outputcontext framework for assessing educational quality was adopted to select appropriate variables. This framework associates hypothetical effectivenessenhancing conditions with output, usually calculated in terms of student achievement. The framework has also been used by many researchers to examine similar issues in the African context (see Fuller and Clarke, I994; Heneveld and Craig, I996). According to Creemers and Schereens (I994), inputs consist of a range of variables associated with financial or personal resources such as students' prior attainment and background, teachers' characteristics and level of education and training, facilities, the curriculum and financial and other resources. Process refers to factors within the school that distinguish effective from less effective schools e.g., the forms of interaction between teachers, students and administrators, material and educational technology. Context, on the other hand, refers to the socio-economic and educational context of schools (e.g., guidelines and regulations for schools and the characteristics/structure of formal educational systems). Outputs typically refer to changes in student achievement, completion rates, certification, skills and certain attitudes and values. The specific aspects of the model examined were the inputs (e.g., prior attainment, background, SES) and output (students' end-of-semester results) and the relationship between them. The framework therefore provided a broader perspective on quality within the institution by assisting the selection of appropriate variables for the study as well as the statistical models. The VA approach was selected due to its ability to take into account differences in the student mix and capture institutions' positive impact on students' learning (Thomas, 200I).

\section{Datasets}

The study used two separate cohort datasets for 2009 and 2007-2009. The reason was that age and gender were not statistically significant when the 2009 dataset was used, perhaps because of its relatively small size. Although age and gender were significant in the 2007-2009 dataset, it did not contain SES information. The 2009 dataset included information on SES gathered via a student survey that elicited information on a variety of issues including the language spoken by students and their place of residence. The total population for the 2009 dataset was between I 757 (CL) and I 822 (AFS). For the 2007-2009- datasets, the total population ranged from 5879 (CL) to 5944 (AFS). Permission was granted by MET Polytechnic to access the datasets on the understanding that the study's findings could benefit the institution in terms of improving teaching and learning. For this reason, a pseudonym, MET Polytechnic, is used. The datasets were created using data from the following three sources:

a) Secondary data

i) From end-of-first-semester examination scores in AFS, Communication Skills (CSI) and Computer Literacy (CLI).

ii) Second semester scores in Communication Skills (CS2) and Computer Literacy (CL2). CS2 is a continuation of $\mathrm{CS}_{1}$ and the same is true of CLI and CL2.

b) Administrative records in the form of students' grades in English, Maths and Science.

c) Student survey data on background and SES.

A dataset was created for each outcome - AFS, CS and CL. For more details, see Table 2 in the Appendix. The significance of the individual variables tested is set out in Table 3 in the Appendix. The individual variables examined were prior attainment, background factors, SES factors and department context.

\section{Prior attainment}

Students' previous grades (A - F) in English language (simply called English), Maths and Science in the West African Senior Secondary School Certificate Examinations (WAEC) were collected from individual student files and used as prior attainment measures (entry level attainment into tertiary education). The WAEC is a consortium of five African countries responsible for all national pre-tertiary examinations in member countries. Obtaining the actual scores instead of grades was a bureaucratic and difficult process. Moreover, sifting the raw scores (with the WAEC's permission) from the thousands of students who wrote the exams across the country in different years (but were part of the group under consideration); 
and matching them with their semester results was problematic. The ideal choice was to convert the grades into class-midpoint averages.

Nevertheless, the grades and their numerical equivalents were available (the ranges of scores and their numerical equivalences are attached in Table I in the Appendix). Class-mid-point equivalents were therefore entered for each student and used as entry level scores to predict the student's performance at tertiary level. This reduced the variability in the dataset. The limitation of this approach or the crude nature (not highly differentiated) of the prior attainment measures used is thus acknowledged and careful consideration and use of the findings is recommended. Furthermore, the study is a pilot of the VA approach in HE in Ghana. It is therefore anticipated that future studies will address this challenge. CSI and CLI as prior attainment, in addition to English, Maths and science proved superior predictors for CS2 and CL2, probably because of their direct relatedness. This highlights the importance of prior attainment measures that are directly relevant to an outcome.

\section{Background}

The following student background variables - gender, age, and language spoken - were statistically adjusted for:

\section{Student gender}

Gender was treated as a binary dummy variable. Females were used as the reference category (female $=0$, males $=\mathrm{I}$ ).

\section{Student age}

Age was measured in months (to decrease the possibility of aggregation of the variable since most of the students were around the same age) and entered for each student.

\section{Language}

Language was treated as a dummy variable $($ Akan $=0$, Ewe $=\mathrm{I}$, Mole-Dagbane [simply called Dagbane] $=2$, Guan $=3$, Ga-Adangbe [simply called Ga] $=4)$. However, some of the variables were re-coded in the multilevel analysis as all of them except the Ga language proved statistically significant. The re-coding was as follows: $\mathrm{Ga}=0$, all other languages $=\mathrm{I}$.

\section{SES}

Socioeconomic status included type of secondary school attended, educational/employment status of both mother and father, language spoken and where the student lived during vacations (residence). Only residence proved statistically significant at .050 level when tested individually and in a group and it was thus included in the analysis. This variable was treated as a dummy $($ city $=0$, district capital $=\mathrm{I}$, town $=2$, and rural area $=3$ ).

\section{Department context}

Mean prior attainment in English, Maths and Science and/or CSI/CLI were used as department context/peer factors. For the first semester courses (AFS, CSi and CLI), prior attainment in English, Maths and Science was used. For the second semester courses (CS2 and CL2), English, Maths and Science and CSI/CLI were used, respectively.

\section{Modelling strategy}

The datasets were analysed using multilevel modelling in line with the hierarchical structure of the datasets (students within departments). This offered several advantages. Firstly, it allowed the variation in student achievement to be classified into individual-level and group-level components that facilitated the calculation of intra-class correlations. Secondly, it enabled the explanatory variables to be placed at their correct levels in the data hierarchy instead of aggregation or disaggregation of the data to a single level of analysis (Heck, 2007). MLwiN2.24 software was used to generate the different statistical models called Models I - 4 across the courses. A two-level statistical model with department at level 2 and student at level I was developed for all the courses.

For the 2009 dataset, the following models were developed:

a. Model I with no explanatory variable.

b. VA Model 2 adjusting for prior attainment only (English, Maths, Science and CSI/CLI).

c. VA Model 3 additionally adjusting for background (language) and SES (residence).

d. VA Model 4 (4A) additionally adjusting for department context (mean prior attainment).

For the 2007-2009 dataset, the VA Model 4A controlling for the following were:

a. Model I with no explanatory variable

b. VA Model 2 Prior attainment (English, Maths, Science and CSI/CLI)

c. VA Model 3 Background (gender and age)

d. VA Department context (mean prior attainment).

These variables were first added individually to the fixed part of the models to establish if they were statistically significant (at .05 significance level). Significant individual variables were then added in groups to assess their 
relevance in explaining the students' performance. A consistent set of explanatory variables for the models was selected based on the criterion that they were statistically significant (I.96 times larger than the associated standard error) when tested individually and together for at least one of the outcomes (Yu and Thomas, 2008). Table 3 in the Appendix presents the list of significant explanatory variables included in the final models. The table also displays those variables that were excluded due to non-significance.

\section{Results}

The results of the study are presented as follows: The descriptive statistics are presented, followed by a discussion on the 'goodness of fit' of the models, and the variables' effect on performance. It is important to note that constant comparisons are made between the first semester outcomes (AFS, CLI and CSI) on the one hand; and the second semester outcomes (CL2 and $\mathrm{CS}_{2}$ ) on the other in order to avoid repetition. Furthermore, most of the comparisons were based on the estimates of Model 4. Model 4A (using the 2007-2009 dataset) is only used to examine the effect of age and gender on performance because these were not significant when using the 2009 dataset.

Tables 2 and 3 in the Appendix present descriptive statistics for both datasets on: (I) the outcomes and (2) previous achievement. For example, the students' average scores using the 2009 dataset were between $60 \%$ (CS2) and $7 \mathrm{I} \%$ (AFS). Thus, on average, the scores were comparatively high in $\mathrm{AFS}$ and lowest in CS2. The standard deviations (SD) were in the range of 9.3 (CSI) and Io.6 (CLI/CL2). In other words, scores in CLI/CL2 were more dispersed from the mean than in CSI. The highest and lowest averages in the case of the 2007-2009 dataset were 69\% in AFS and 60\% in CS2. The highest and lowest SDs were I2.3 (CS2) and 9.I (CLI), respectively.

In terms of prior attainment, the highest and lowest averages were between 55\% (Science) and 59\% (English) using the 2009 dataset. Equivalent values in the case of the 2007-2009 dataset were 57\% (Maths) and $55 \%$ (Science). The average age in years using the same dataset was 21.6 (3.5). According to the 2009 dataset, many students (75\%) spoke the Akan language while very few (I\%) spoke the Dagbane language. The majority $(58 \%)$ also lived in cities while few $(9.40 \%)$ stayed in rural areas (see Table 4 in the Appendix).

Model 2: Adjusting for prior attainment only (2009 dataset)

With respect to the 'goodness of fit' of the models, Model I was used as the baseline model to calculate the total percentage variance explained by the VA models. The total variance explained by Model 2 was on average $3 \%$ for AFS, CLI and CSI and I4\% for CL2 and CS2 (see Table 6 in the Appendix).
Clearly, English, Maths and Science were very poor at predicting the students' performance in AFS, CLI and CSI (see the discussion for possible reasons). Nevertheless, the addition of CSI/CLI for CS2/CL2 improved the 'goodness of fit' (I4\%); perhaps highlighting the important role played by prior attainment measures directly related to a course in this kind of analysis (see Table 6 in the Appendix).

Model 3: Additionally, adjusting for background and SES (2009 and 20072009 datasets)

Model 3 explained $2 \%$ and I $4 \%$ of the total variance for the first and second semester outcomes, respectively (see Table 7 in the Appendix). A comparison of Model 3 with Model 2 in terms of equivalent values shows a slight decrease ( 0.7 percentage points). This suggests that the variables adjusted for by Model 3 were poor at predicting the students' performance. Indeed, the majority of the SES factors examined by the study were statistically insignificant at .05 significance level when tested individually and together. These included the type of secondary school attended, the location of the secondary school the student attended (rural/urban) and the educational/ employment status of both mother and father.

The students' ethnic group and residence were statistically significant at .05 significance level; indicating that these two variables were perhaps important in understanding differences in their VA performance. As demonstrated by the Model 3 estimates (accounting for students' background and SES) on average, Ga-Adamgbe students underachieved in African Studies by .2I5 units compared to the performance of the other four ethnic groups together (Akan, Ewe, Mole-Dabagbane and Guans).

With regard to the students' residence, the Model 3 estimates showed that, on average, students who resided in district capitals obtained .I57 more units in CSI than those who lived in cities. This finding suggests that, overall, students who lived in cities had lower levels of academic performance than those who resided in district capitals.

Model 4: Additionally, adjusting for department context (2009)

The average total variance explained by Model 4 using the 2009 dataset was 9\% (AFS, CLI and CSI) and I8\% (CL2 and CS2) (see Table 8 in the Appendix). Comparatively, Model 4 explained more of the total variance. On average, Model 4A (using the 2007-2009 dataset) explained 2\% (AFS, CLI and $\mathrm{CS}_{1}$ ) and $23 \%$ (CL2 and $\mathrm{CS}_{2}$ ) of the total variance (see Table 9 in the Appendix).

The Effect of the selected variables (Model $4 \mathrm{~A}$ and 4 )

This section focuses on the effect of statistically significant variables in the 
fixed part of the model using both datasets, but most often the 2009 one. The fixed effects of prior attainment, background, SES and mean prior attainment (department) are examined.

\section{Prior attainment (Model 4)}

The fixed effects of the prior attainment measures of mean English, Maths and Science (across all five outcomes) and CSI/CLI for CS2 and CL2 are examined here. Using the 2009 dataset (Model 4), English impacted positively on AFS but negatively on CL2. On average, an increase of one standardised unit (simply called a unit) in English resulted in an increase of .I6I units in AFS but a decrease of .07I units in CL2. The finding that, those with lower attainment in English performed relatively better in CL2 is surprising. However, as De Keyser, Van Patten and Williams (2007, p. 96) explain in their Skill Acquisition Theory, "A central concept in the study of skill acquisition is the power law of learning which formalizes mathematically what has been observed many times. That both reaction time and error rate decrease systematically as a consequence of practice". Based on this theory and the fact that CL is a predominantly practical course, it is possible that those with low English attainment practiced more (e.g., at school computer laboratories or sought help through private tuition) than those with good grades in English. Further research is required on this issue.

Science also impacted positively on AFS. Thus, an average increase of one unit in Science increased the students' performance in AFS by .o80 units. The effect of $C S_{1}$ on $C_{2}$ was also positive, and the same was true of CL1 on CL2. Not surprisingly, an average increase of one unit in $C_{1}$ increased the students' performance in $\mathrm{CS}_{2}$ by .384 units. A one-unit increase in CL1 similarly increased the students' performance in CL2 by .323 units (see Table 8 in the Appendix).

\section{Student background and SES (Model 4 Model $4 \mathrm{~A}$ )}

The fixed effects of the individual background factors of language and residence are examined here. Language impacted negatively on AFS. Thus, Ga-speaking students obtained $\mathbf{2 2 2}$ less units in AFS relative to those who spoke Akan, Ewe, Dagbane and Guan put together. The effect of age on three of the outcomes (CSI, CLI and CS2) was negative using the 20072009 dataset. On average, older students obtained .oI8 less units in CSI, .032 less units in CLI and .oI2 less units in CS2 than younger students (see Table 9 in the Appendix). Students' gender impacted positively on AFS but negatively on CLI. On average, females outperformed their male counterparts in AFS by .II4 units. However, males obtained .roo more units in CLI than their female counterparts (see Table 9 in the Appendix).
Department context (Model 4 and Model $4 \mathrm{~A}$ )

The variables examined here include mean prior attainment in English, Maths, Science and CSI/CLI. The overall effect of these variables was mixed and outcome specific (Appendix: Tables 7 and 8). Using the 2009 dataset, mean Maths impacted positively on AFS. Thus, one SD increase in mean Maths increased performance in AFS by I.422 units of a SD. As expected, mean CS1 impacted positively on $\mathrm{CS}_{2}$, i.e., one SD increase in mean $\mathrm{CS}_{\mathrm{I}}$ enabled students to improve their scores in CS2 by .384 units of a SD. The positive effects generally suggest that students in departments with high mean prior attainment gained more in terms of learning than those in departments with low mean prior attainment. This finding is consistent with previous studies that reported a significantly positive association between peer quality and academic achievement (Hoxby, 2000a; Winston and Zimmerman, 2003).

In terms of negative effects, mean English impacted negatively on AFS. That is, an increase of one SD in mean English resulted in a decrease of .487 units of one SD in AFS. Mean Science similarly impacted negatively on AFS. That is, an increase of one SD in mean Science resulted in a decrease of .939 units of one SD. The negative effects generally suggest that students in departments with high mean prior attainment measures gained less in terms of learning than those in departments with low mean prior attainment measures (see Appendix: Table 9). In other words, if a low achieving student is among students with high mean achievement, $\mathrm{s} / \mathrm{he}$ is more likely to perform worse. Rutter and Maughan (2002) explain that students who attend schools with high average attainment tend to have lower self-esteem and possibly, perform poorly (due to negative contrast effects), although there may also be a counterbalancing positive assimilation effect (e.g., glory or pride in the school).

\section{Discussion}

The following two key findings are discussed in line with the existing literature and contextual evidence; (I) the 'goodness of fit' of the models; and (2) the effect of the selected variables on performance.

Broadly speaking, Models I-3 were not very good at predicting the students' performance in the selected courses. For instance, the total variance explained by Model 2 adjusting for prior attainment only was 3\% (AFS, CLI and $\left.\mathrm{CS}_{1}\right)$ and $\mathrm{I}_{4} \%$ (CL2 and CS2). Compared to similar studies at tertiary level, the estimates were particularly low for the first semester outcomes. For instance, Johnes' (2006) investigation of the distribution of degree results across four broad subject categories using students' entry scores, explained II-I2\% of the total variance for the Pure and Applied Sciences and $7-8 \%$ for the Social Sciences and the Arts subject categories after adjusting 
for prior attainment. Similarly, Chapman (I996) found that the proportion of variability in student performance explained by entry qualifications was between $5 \%$ and $24 \%$ for Mathematics.

The poor goodness of fit of the models could be due to several reasons. In the case of Model 2 that considered the first semester outcomes (AFS, CLI and CSI), it could be due to the class mid-point averages used for English, Maths and Science (that were not highly differentiated). Another possibility could be differences in support for examinations at the secondary and tertiary levels. For example, the WAEC exams are high-stake exams. Hence, most Ghanaian secondary schools tend to focus on specific curriculum areas (becoming results-oriented) and neglect other aspects of the curriculum that promote students' total development. Students are also exposed to past/likely examination questions through school or privately organised extra tuition (usually after school hours, and during weekends and vacations). Simply put, the WAEC exams are made relatively easy for students compared to exams at the tertiary level where self-discipline and hard work are the key to success.

Another possible explanation is changes in teaching methods between pre-tertiary and tertiary levels. The predominant teaching method at pretertiary level (student-centred) is usually replaced by the lecture method (teacher-centred) at the tertiary level. Thus, instead of students being passive listeners jotting down notes while the teacher teaches, they become active listeners, noting important points with little opportunity to ask questions or become involved in the learning process (Maduewesi, I999). Tertiary teachers may also cover a great deal of material within a short period of time without consideration for differences in students (some of whom might be slow learners, or have low levels of ability) (Vin-Mbah, 20I2). The 'new' responsibility of having to independently digest large volumes of information within a short period of time might have been daunting for some. It is thus possible that slow adaptors achieved less academically despite the fact that they entered the polytechnic with good grades.

Furthermore, students who enter tertiary education may need to adjust to a number of other challenges in their personal and academic lives. For example, increased self-regulation is expected from tertiary students if they are to cope with the time pressure inherent in higher education (Eggens, Werf and Bosker, 2008). In school, their time was managed by the school authorities and parents who mainly directed it towards academic work. Thus, it is possible that previously high achieving students could underperform at tertiary level due to poor time management. Some students might devote more time to non-academic activities such as entertainment, religious and sporting activities, vying for position, politics, fashion/grooming, etc. due to the apparent freedom offered by the tertiary environment.
A comparison of the equivalent values of Model 3 and Model 2 shows that the total variance between departments decreased by an average of one percentage point across the first semester outcomes but remained the same across the second semester outcomes, indicating that the students' background and SES were not good at predicting the students' performance. This is in contrast to numerous studies that found that students with high SES perform better academically than those with low SES (see Yu and Thomas, 2008; Muijis and Reynolds, 2003; Horn and Bobbitt, 2000). In terms of SES, to a greater or lesser extent, the majority of the individual variables did not prove statistically significant at .050. This included the type of secondary school attended and the educational/employment status of both mother and father. It is possible that these factors did not affect the students' performance because the Polytechnic was able to identify and respond to potentially disruptive situations in order to prevent low performance especially for those at greatest risk (Auwarter and Aruguete, 2008). Further research is recommended on this issue.

The students' language and residence was statistically significant at .05 significance level, suggesting that these variables were important in understanding their VA performance. As demonstrated by the Model 3 estimates (accounting for students' background and SES), on average, Ga-Adamgbe students underachieved in African Studies by .2I5 units compared to the performance of the other four ethnic groups together (Akan, Ewe, Mole-Dabagbane and Guans). Although further research is necessary to ascertain why Ga-Adamgbe students underachieved, Eggens, Werf and Bosker (2008, p. 553) explain that "the extent to which students succeed in integrating into a new tertiary environment and the amount of social support they receive from network members possibly determine part of their academic success or failure." Lesser and Storck (200I) observe that people who share a common language although not co-located, may form relationships based on a sense of trust and mutual obligation and this may facilitate access to people and information.

The students' residence (city, district capital, town or rural area) also impacted positively on CSI. On average, students who resided in district capitals obtained .I56 more units in CSI than those who lived in cities (see Table 8 in the Appendix). This suggests that, in general, students who lived in cities achieved lower levels of academic performance than those who resided in district capitals. According to Zhang (2006), such differences may be due to discrepancies in the resources available in rural and urban areas. In Ghana, communities have differential access to infrastructure such as libraries, the Internet, and electricity as well as opportunities to learn (e.g., resource persons, attachment, placement, etc.). This suggests that pre-tertiary students who lived in areas with limited resources were 
disadvantaged academically. However, once they enter tertiary education where all students have equal access to available facilities, they are more likely to take advantage of opportunities and improve their performance. Those from less endowed areas may also be more motivated to improve their performance because members of their community look up to them.

Model 4, statistically adjusting for students' prior attainment, background and department context explained more of the total variance - 9\% (AFS, CLI and CSI) and I8\% (CS2 and CL2). In terms of equivalent values, Model 4 registered an improvement over Model 2 of six and four percentage points, respectively. Improvements of seven and four percentage points were similarly seen in the case of Model 3. These small improvements highlight the important role played by school-related factors (e.g., department context) compared to out-of-school factors when it comes to explaining differences in student performance (Fuller and Clarke, I994; Al口Nhar, I999).

However, the effect of individual factors on performance was mixed and outcome specific. For example, age impacted negatively on three of the outcomes (CSI, CLI and CS2). In general, younger students performed better than their older counterparts. This finding is consistent with those of Richardson (I994) who concluded that mature students are at a disadvantage when pursuing higher education. Wößmann (2003), who used an international database of more than 260000 students in 39 countries, also found that age was negatively related to performance. Students' gender also had mixed effects. Evidence on the differences in the performance of male and female students in higher education have often proved highly controversial or inconclusive (Chapman, I996; Rodgers, 2007). However, some studies have found that females have a marginal edge over males (Rodgers and Ghosh, 200I; Smith and Naylor, 200Ia). Explanations offered in the literature include bias in markers and stereotypes such as markers expecting males to do well (Hartley and Lapping, I992).

\section{Conclusion}

On average, Model 4 (controlling for prior attainment, background, SES and mean prior attainment) explained more of the total variance (9\%) and (I8\%) across the first and second semester outcomes than Model 3 controlling for students' background and SES ( $2 \%$ and I4\%, respectively) and Model 2 adjusting for prior attainment measures only (3\% and I4\%, respectively). However, in contrast to the findings of numerous other studies, weak correlation was established between the selected predictors (prior attainment, background and SES) and the outcomes measures. Possible reasons include the use of class mid-point averages as prior attainment; high-stake exams, changes in teaching methods between the pre-tertiary and tertiary levels; levelling in facilities and opportunities to learn; and the extent to which students succeed in integrating into the tertiary environ- ment. These estimates further indicate that other factors apart from the above may be responsible for the VA differences in the performance of tertiary students. However, the effect of the selected variables on performance was mostly mixed and outcome specific, suggesting that specific student variables may be related to specific courses (e.g., CSI and CS2; CLI and CL2).

The students' ethnic group and residence tested statistically significant; perhaps suggesting the importance of these variables in understanding tertiary students' VA performance. Although further research is necessary to ascertain why the Ga-Adamgbe students underachieved, support from fellow students who spoke similar languages or otherwise, possibly, explains the observed differences. With regard to the students' residence, the study generally suggested that, students who lived in cities achieved less academically relative to those who resided in district capitals. A probable explanation is equal access to resources at the tertiary level as against the pre-tertiary level.

\section{Recommendations}

The following recommendations are made:

I. A key finding of this study was that prior attainment measures directly related to an outcome may be a better predictor of students' performance in similar prospective courses. Based on this, it is recommended that the relatedness of previous knowledge to a prospective course/ programme should be considered in selecting students for courses/ programmes during admission or teaching/ learning.

2. Further research using finely differentiated 'raw' scores as prior attainment measures (possibly from WAEC) is necessary to clarify and explain why the prior attainment measures proved poor at predicting the students' performance.

3. Based on the study's limitation that it was difficult to obtain equivalent data from analogous institutions, it is recommended that a national body like the National Board for Professional and Technician Examinations should establish a relevant institutional database to support future research on how to support student learning drawing on factors that influence their learning. 


\section{References}

Al-Nhar, T. (I999). Determinants of Grade 8 achievement in Jordan: A multilevel analysis approach. Educational Psychology 19(I), 37-52.

Armstrong, D., and McVicar, D. (2000). Value added in further education and vocational training in Northern Ireland. Applied Economics 32(I3), I727-I736.

Auwarter, A. E., and Aruguete, M. S. (2008). Effects of student gender and socioeconomic status on teacher perceptions. The Journal of Educational Research 101(4), 242-246.

Barrie, S. C. (2006). Understanding what we mean by the generic attributes of graduates. Higher Education 5I(2), 2I5-24I.

Bowden, R. (2000). Fantasy higher education: University and college league tables. Quality in Higher Education 6(I), 4I-60.

Bratti, M., McKnight, A., Naylor, R., and Smith, J. (2004). Higher education outcomes, graduate employment and university performance indicators. Journal of the Royal Statistical Society: Series A (Statistics in Society) I67(3), 475-496.

Chapman, K. (I996). Entry qualifications, degree results and value-added in UK universities. Oxford Review of Education 22(3), 25I-264.

Chiao, C., and Chiu, C. H. (20I8). The mediating effect of ICT usage on the relationship between students' socioeconomic status and achievement. The Asia-Pacific Education Researcher 27(2), I09-I2I.

Creemers, B. P., and Scheerens, J. (I994). Developments in the educational effectiveness research programme. International Journal of Educational Research 21(2), I25-I4O.

Fuller, B., and Clarke, P. (I994). Raising school effects while ignoring culture? Local conditions and the influence of classroom tools, rules, and pedagogy. Review of Educational Research 64(I), II9-I57.

De Keyser, R., Van Patten, B., and Williams, J. (2007). Skill acquisition theory. Theories in second language acquisition: An introduction, 97II3.

Eggens, L., Van der Werf, M. P. C., and Bosker, R. J. (2008). The influence of personal networks and social support on study attainment of students in university education. Higher Education 55(5), 553-573.

Erdogdu, F., and Erdogdu, E. (20I5). The impact of access to ICT, student background and school/home environment on academic success of students in Turkey: An international comparative analysis. Computers and Education 82, 26-49.

Evans, M. (2000). Planning for the transition to tertiary study: A literature review. Journal of Institutional Research 9(I), I-I3.

Fuller, B., and Clarke, P. (I994). Raising school effects while ignoring culture? Local conditions and the influence of classroom tools, rules, and pedagogy. Review of Educational Research 64(I), II9-I57.

Gardner, S. K. (2005). "If it were easy, everyone would have a Ph. D."
Doctoral student success: Socialization and disciplinary perspectives. Washington State University.

Hartley, J., and Lapping, C. (I992). Do mature students of psychology perform as well as traditional entry ones? An analysis of archival data. Psychology Teaching Review 1(I), 76-8I.

Heck, R. H. (2008). Teacher effectiveness and student achievement investigating a multilevel cross-classified model. Journal of Educational Administration 47, (2),227-249.

Heneveld, W., and Craig, H. (I996). Schools count: World Bank project designs and the quality of primary education in Sub-Saharan Africa (Vol. 303). World Bank Publications.

Horn, L., and Bobbitt, L. (2000). Mapping the road to college: First generation students' math track, planning strategies, and context of support (NCES Publication No. 2000-I53). Washington, DC: U.S. Government Printing Office.

Hoskins, S. L., Newstead, S. E., and Dennis, I. (I997). Degree performance as a function of age, gender, prior qualifications and discipline studied. Assessment and Evaluation in Higher Education 22(3), 3I7-328.

Houston, D. (2008). Rethinking quality and improvement in higher education. Quality Assurance in Education 16(I), 6I-79.

Hoxby, C. (2000). Peer effects in the classroom: Learning from gender and race variation (No. w7867). National Bureau of Economic Research.

Johnes, J. (2006). Measuring efficiency: A comparison of multilevel modelling and data envelopment analysis in the context of higher education. Bulletin of Economic Research 58(2), 75-104.

Jung Peng, W., Thomas, S. M., Yang, X., and Li, J. (2006). Developing school evaluation methods to improve the quality of schooling in China: a pilot 'value added' study. Assessment in Education: Principles, Policy and Practice 13(2), I35-I54.

Koedel, C., Mihaly, K., and Rockoff, J. E. (2015). Value-added modelling: A review. Economics of Education Review 47, I80-195.

Kuh, G. D., Kinzie, J. L., Buckley, J. A., Bridges, B. K., and Hayek, J. C. (2006). What matters to student success? A review of the literature (Vol. 8). Washington, DC: National Postsecondary Education Cooperative.

Kuh, G. D. (200I). Assessing what really matters to student learning inside the national survey of student engagement. Change: The Magazine of Higher Learning 33(3), IO-I7.

Kupermintz, H. (2003). Teacher effects and teacher effectiveness: A validity investigation of the Tennessee Value Added Assessment System. Educational Evaluation and Policy Analysis 25(3), 287-298.

Ladd, H. F., and Walsh, R. P. (2002). Implementing value-added measures of school effectiveness: Getting the incentives right. Economics of Education Review 21(I), I-I7. 
Lesser, E. L., and Storck, J. (200I). Communities of practice and organizational performance. IBM Systems Journal 40(4), 83I-84I.

Maduewesi, B.U. (I999). General Curriculum Methodology. Nigeria: Joy Educational Publishers.

Marginson, S. (I993). From cloister to market: The new era in higher education. Journal of Tertiary Educational Administration 15(I), 43-64.

Mills, C., Heyworth, J., Rosenwax, L., Carr, S., and Rosenberg, M. (2009). Factors associated with the academic success of first year health science students. Advances in Health Sciences Education 14(2), 205-2I7.

Muijs, D., and Reynolds, D. (2003). The effectiveness of the use of learning support assistants in improving the mathematics achievement of low achieving pupils in primary school. Educational Research 45(3), 219-230.

Muslim, N., Alias, J., Mansor, A. Z., Salleh, A. R., and Basir, A. (20I2). Viewpoint of Students of National University of Malaysia on Generic Skill Courses. World Applied Sciences Journal 18(6), 754-76r.

Osborne, M. (2003). Increasing or widening participation in higher education? A European overview. European Journal of Education 38(I), 5-24.

Pascarella, E. T., and Terenzini, P. T. (2005). How College Affects Students: A Third Decade of Research. Volume 2. Jossey-Bass, An Imprint of Wiley. I0475 Crosspoint Blvd, Indianapolis, IN 46256 .

Pascarella, E. T. (200I). Identifying excellence in undergraduate education: Are we even close? Change: The Magazine of Higher Learning 33(3), I8-23.

Rodgers, T. (2007). Measuring value added in higher education: A proposed methodology for developing a performance indicator based on the economic value added to graduates. Education Economics 15(I), 55-74.

Richardson, J. T. E. (I994). Mature students in higher education: Academic performance and intellectual ability. Higher Education 28, 373-386.

Rodgers, T. (2007). Measuring value added in higher education: A proposed methodology for developing a performance indicator based on the economic value added to graduates. Education Economics 15(I), 55-74.

Rodgers, T., and Ghosh, D. (200I). Measuring the determinants of quality in UK higher education: A multinomial logit approach. Quality Assurance in Education 9(3), I2I-I26.

Rubenstein, R., Schwartz, A. E., and Stiefel, L. (2003). Better than raw: A guide to measuring organizational performance with adjusted performance measures. Public Administration Review 63(5), 607-615.

Rumberger, R., and Palardy, G. (2005). Does segregation still matter? The impact of student composition on academic achievement in high school. The Teachers College Record 107(9), I999-2045.

Rumberger, R.W., and Palardy, G.J. (2004). Multilevel models for school effectiveness research. In: D. Kaplan (ed.) Handbook of quantitative methodology for the social sciences, pp. 235-258. Thousand Oaks, CA: Sage.
Rutter, M., and Maughan, B. (2002). School effectiveness findings I9792002. Journal of School Psychology 40(6), 45I-475.

Sammons, P., Day, C., Kington, A., Gu, Q., Stobart, G., and Smees, R. (2007). Exploring variations in teachers' work, lives and their effects on pupils: Key findings and implications from a longitudinal mixed method study. British Educational Research Journal 33(5), 68I-70I.

Sammons, P., Thomas, S., and Mortimore, P. (I997). Forging links: Effective schools and effective departments. Sage.

Santos, A. I., and Serpa, S. (20I7). The importance of promoting digital literacy in higher education. Int'l J. Soc. Sci. Stud. 5, 90.

Scheerens, J. (2005). Review of school and instructional effectiveness research. Paper commissioned for the EFA Global Monitoring Report.

Scheerens, J., and Bosker, R. (I997). The foundations of educational effectiveness. Pergamon.

Smith, J., and Naylor, R. (200I). Determinants of degree performance in UK universities: a statistical analysis of the I993 student cohort. Oxford Bulletin of Economics and Statistics 63(I), 29-60.

Tam, M. (200I). Measuring quality and performance in higher education. Quality in Higher Education 7(I), 47-54.

Teichler, U. (2003). The future of higher education and the future of higher education research. Tertiary Education and Management 9(3), I7I-I85.

Thomas, S. (200I). Dimensions of Secondary School Effectiveness: Comparative Analyses Across Regions. School Effectiveness and School Improvement 12 (3) 285-322.

Thomas, S., and Mortimore, P. (I996). Comparison of value-added models for secondary $\square$ school effectiveness. Research Papers in Education 11(I), 5-33.

Vin-Mbah, F. I. (20I2). Learning and teaching methodology. Journal of Educational and Social Research 2(4), III.

Wößmann, L. (2003). Schooling resources, educational institutions and student performance: the international evidence. Oxford Bulletin of Economics and Statistics 65(2), II7-I7O.

Winston, G. C., and Zimmerman, D. J. (2003). Peer Effects in Higher Education. Discussion Paper.

Yin, R. K. (2009). Case study research: Design and methods (4th ed.). Los Angeles and London: Sage.

Yu, G., and Thomas, S. M. (2008). Exploring school effects across southern and eastern African school systems and in Tanzania. Assessment in Education: Principles, Policy and Practice 15(3), 283-305.

Zhang, Y. (2006). Urban-rural literacy gaps in Sub-Saharan Africa: The roles of socioeconomic status and school quality. Comparative Education Review 50(4), 58I-602. 


\section{Appendix}

Table 1: WASSCE Grades and Their Numerical Equivalents

\begin{tabular}{|l|c|c|c|c|}
\hline Grade & $\begin{array}{l}\text { Numerical } \\
\text { representation }\end{array}$ & Interpretation & $\begin{array}{l}\text { Percentage } \\
\text { mark obtained/\% }\end{array}$ & $\begin{array}{l}\text { Class Mid- } \\
\text { points/\% }\end{array}$ \\
\hline A & 1 & Excellent & 70 and above & 70 \\
\hline B & 2 & Very good & $65-69$ & 67 \\
\hline C & 3 & Good & $60-64$ & 62 \\
\hline D & 4 & Credit & $55-59$ & 57 \\
\hline E & 5 & Pass & $50-54$ & 52 \\
\hline F & 0 & Fail & 49 and below & 49 \\
\hline
\end{tabular}

\section{Source: WAEC, 2009}

Table 2: Missing Data and Descriptive Statistics on the Datasets (SD in Brackets)

\begin{tabular}{|c|c|c|}
\hline & 2009 & $2007-2009$ (Total) \\
\hline \multicolumn{3}{|l|}{ Sample size } \\
\hline African Studies (AFS) & 1822 & 5944 \\
\hline CSiand CS2 & 1759 & 5881 \\
\hline $\mathrm{CL} 1$ and $\mathrm{CL} 2$ & 1757 & 5879 \\
\hline Total & 5338 & \\
\hline \multicolumn{3}{|l|}{ Descriptive Statistics } \\
\hline \multicolumn{3}{|l|}{ Means of Outcomes } \\
\hline African Studies & $71.0(9.9)$ & $69.1(10.7)$ \\
\hline CS1 & $60.2(9.3)$ & $60.6(9.1)$ \\
\hline $\mathrm{CL}_{1}$ & $65.0(10.6)$ & $64.9(10.6)$ \\
\hline $\mathrm{CS} 2$ & $59.8(10.1)$ & $60.1(12.3)$ \\
\hline $\mathrm{CL} 2$ & $63.0(10.6)$ & $64.2(11.5)$ \\
\hline \multicolumn{3}{|c|}{ Means of Outcomes (Missing Data) $n=449$} \\
\hline African Studies & $68.1(10.3)$ & \\
\hline CS1 & $59.4(8.7)$ & \\
\hline CL1 & $60.3(9.9)$ & \\
\hline $\mathrm{CS} 2$ & $66.2(11.2)$ & \\
\hline $\mathrm{CL} 2$ & $64.8(12.0)$ & \\
\hline \multicolumn{3}{|c|}{ Prior attainment and Age (Main Study) } \\
\hline English & $59.2(3.1)$ & $55.2(2.3)$ \\
\hline Maths & $57.1(5.2)$ & $56.9(5.4)$ \\
\hline Science & $55.4(4.2)$ & $55.0(4.2)$ \\
\hline Age (years) & $21.7(2.4)$ & $21.6(3.5)$ \\
\hline \multicolumn{3}{|c|}{ Prior attainment and Age (Missing Data) $n=449$} \\
\hline English & $56.3(4.2)$ & \\
\hline Maths & $56.3(5.4)$ & \\
\hline Science & $54.9(4.5)$ & \\
\hline Age (in months) & $21.9(2.7)$ & \\
\hline
\end{tabular}

Table 3: The Significance of the Selected Variables for Models 1-4 and model 4A for Each Outcome (2009 and 2007-2009 Datasets)

\begin{tabular}{|c|c|c|c|c|c|}
\hline \multirow[b]{2}{*}{ Model } & & Tested & & $\begin{array}{l}\text { Included } \\
\text { (v)/ }\end{array}$ & \begin{tabular}{|l} 
Excluded \\
$(x)$
\end{tabular} \\
\hline & & \begin{tabular}{|l}
2009 \\
Dataset
\end{tabular} & $\begin{array}{l}2007-9 \\
\text { dataset }\end{array}$ & \begin{tabular}{|l|}
2009 \\
Dataset
\end{tabular} & $\begin{array}{l}\text { 2007-2009 } \\
\text { Dataset }\end{array}$ \\
\hline \multirow[t]{11}{*}{2} & Prior attainment & All & All & V All & V All \\
\hline & English & & & & \\
\hline & Maths & & & & \\
\hline & Science & & & & \\
\hline & $\mathrm{CS} 1 / \mathrm{CL}_{1}$ & & & & \\
\hline & Quadratic & All & All & $x$ all & $x$ all \\
\hline & English squared & & & & \\
\hline & Maths squared & & & & \\
\hline & Science squared & & & & \\
\hline & CSi squared & & & & \\
\hline & CLisquared & & & & \\
\hline \multirow[t]{4}{*}{3} & Background & All & & & \\
\hline & Gender & & v & $x$ & v \\
\hline & Age in months & & $\mathrm{v}$ & $x$ & $\mathrm{v}$ \\
\hline & Language & & N/A & $\mathrm{v}$ & N/A \\
\hline \multirow[t]{8}{*}{3} & SES & All & $\mathrm{N} / \mathrm{A}$ & & N/A \\
\hline & Type of secondary school attended & & & $x$ & \\
\hline & Location of secondary school & & & $x$ & \\
\hline & Where the students lived & & & $\mathrm{v}$ & \\
\hline & Mother's educational level & & & $x$ & \\
\hline & Father's educational level & & & $x$ & \\
\hline & Mother's employment & & & $x$ & \\
\hline & Father's employment & & & $x$ & \\
\hline \multirow[t]{5}{*}{4} & Context & All & All & $\checkmark$ All & \\
\hline & Mean English & & & & v \\
\hline & Mean Maths & & & & $x$ \\
\hline & Mean Science & & & & $v$ \\
\hline & Mean $\mathrm{CS}_{1} / \mathrm{CL}_{1}$ & & & & V \\
\hline
\end{tabular}

Note $\mathrm{s}=$ significant $\mathrm{ns}=$ Not significant 
Table 4: Frequencies/Percentage of Students' Background and SES

\begin{tabular}{|l|c|c||l|l|l|l|l|}
\hline & $\begin{array}{l}\text { AFS } \\
\text { Frequency }\end{array}$ & $\%$ & $\begin{array}{l}\text { CS1 and } \\
\text { CS2 } \\
\text { Frequency }\end{array}$ & $\%$ & $\begin{array}{l}\text { CLiandCL2 } \\
\text { Frequency }\end{array}$ & $\%$ \\
\hline Background - Language & 1364 & 74.90 & 1324 & 75.30 & 1317 & 74.90 \\
\hline Akan & 239 & 13.10 & 220 & 12.50 & 223 & 12.70 \\
\hline Ewe & 15 & .80 & 15 & .90 & 15 & .90 \\
\hline Mole-Dagbane & 20 & 1.10 & 20 & 1.10 & 21 & 1.20 \\
\hline Guan & 184 & 10.10 & 180 & 10.20 & 181 & 10.30 \\
\hline Ga-Adamgbe & & & & & & \\
\hline SES & 1066 & 58.50 & 1024 & 58.20 & 1020 & 58.10 \\
\hline $\begin{array}{l}\text { Residence of } \\
\text { student }\end{array}$ & 349 & 19.20 & 337 & 19.20 & 334 & 19.00 \\
\hline City & 237 & 13.00 & 234 & 13.30 & 238 & 13.50 \\
\hline District capital & 170 & 9.30 & 164 & 9.30 & 165 & 9.40 \\
\hline Town & & & & & & \\
\hline Rural area & & & & & \\
\hline
\end{tabular}

Table 5: Model 1 - The Null Model

\begin{tabular}{|c|c|c|c|c|c|}
\hline & AFS & $\mathrm{CS}_{1}$ & $\mathrm{CL}_{1}$ & $\mathrm{CS}_{2}$ & $\mathrm{CL} 2$ \\
\hline \multicolumn{6}{|c|}{ Fixed Part (Coefficient) } \\
\hline $\begin{array}{l}\text { Cons/ } \\
\text { intercepts }\end{array}$ & $0.177[0.141]$ & $0.049[0.114]$ & $0.174[0.090]$ & $0.049[0.114]$ & $\begin{array}{c}0.242 \\
{[0.119]^{*}}\end{array}$ \\
\hline \multicolumn{6}{|c|}{ Random Part (Variances) } \\
\hline $\begin{array}{l}\text { Between } \\
\text { Depts. }\end{array}$ & $0.298[0.112]^{*}$ & $0.187[0.073]^{*}$ & $0.110[0.045]^{*}$ & $\begin{array}{c}0.187 \\
{[0.073]^{*}}\end{array}$ & $\begin{array}{r}0.209 \\
{[0.081]^{* *}}\end{array}$ \\
\hline $\begin{array}{l}\text { Between } \\
\text { Students }\end{array}$ & $\begin{array}{c}0.870 \\
{[0.029]^{*}}\end{array}$ & $\begin{array}{c}0.827 \\
{[0.028]^{*}}\end{array}$ & $0.909[0.031]]^{*}$ & $\begin{array}{c}0.827 \\
{[0.028]^{*}}\end{array}$ & $\begin{array}{c}0.751 \\
{[0.025]^{*}}\end{array}$ \\
\hline Total & 1.168 & 1.014 & 1.019 & 1.014 & 0.960 \\
\hline $\begin{array}{l}\% \text { Variance } \\
\text { attributable to } \\
\text { Departments }\end{array}$ & 26 & 18 & 11 & 18 & 22 \\
\hline
\end{tabular}

Note: * = Statistically significant at .050 significance level
Table 6: Model 2 Controlling for Prior Attainment Measures

\begin{tabular}{|c|c|c|c|c|c|}
\hline & $\begin{array}{l}\text { African } \\
\text { Studies }\end{array}$ & $\mathrm{CS}_{1}$ & $\mathrm{CL}_{1}$ & $\mathrm{CS}_{2}$ & \\
\hline $\begin{array}{l}\text { Cons/ } \\
\text { intercepts }\end{array}$ & $0.185[0.129]$ & $0.047[0.115]$ & $0.178[0.091]$ & $0.014[0.104]$ & 0.178 [0.103] \\
\hline \multicolumn{6}{|c|}{ Prior attainment } \\
\hline English & $0.161[0.024]^{*}$ & $0.009[0.024]$ & 0.004 [0.025] & $-0.021[0.023]$ & $-0.071[0.021]^{\prime \prime}$ \\
\hline Maths & $0.043[0.024]$ & $-0.008[0.025]$ & $0.039[0.026]$ & $-0.004[0.024]$ & $-0.032[0.022]$ \\
\hline Science & $\begin{array}{c}0.087 \\
{[0.025]^{*}}\end{array}$ & $-0.007[0.007]$ & $-0.028[0.026]$ & $-0.004[0.024]$ & $0.009[0.022]$ \\
\hline $\mathrm{CS} / \mathrm{CL}_{1}$ & & & & $0.389[0.023]^{*}$ & $0.326[0.020]^{*}$ \\
\hline \multicolumn{6}{|l|}{ Random Part } \\
\hline $\begin{array}{l}\text { Between Tr./ } \\
\text { Dept. }\end{array}$ & $\begin{array}{c}0.248 \\
{[0.095]^{* *}}\end{array}$ & $0.191[0.074]^{*}$ & $0.111[0.046]^{*}$ & $0.156[0.061]^{*}$ & $0.153[0.059] *$ \\
\hline $\begin{array}{l}\text { Between } \\
\text { Students }\end{array}$ & $\begin{array}{c}0.834 \\
{[0.028]^{* *}}\end{array}$ & $0.827[0.028]^{*}$ & $0.908[0.031]^{*}$ & $0.750[0.025]^{*}$ & $0.651[0.022]^{*}$ \\
\hline Total & 1.082 & 1.018 & 1.019 & 0.906 & 0.804 \\
\hline $\begin{array}{l}\text { \% Variance } \\
\text { explained } \\
\text { at Tr./Dept. } \\
\text { level }\end{array}$ & 17 & 2 & 9 & 17 & 27 \\
\hline Student & 4 & $\circ$ & o & 9 & 13 \\
\hline Total & 9 & $\circ$ & o & 11 & 16 \\
\hline $\begin{array}{l}\text { \%Variance } \\
\text { attributable } \\
\text { to Tr./Dept. }\end{array}$ & 23 & 19 & 11 & 17 & 19 \\
\hline
\end{tabular}

Note: * = Statistically significant at .050 significance level 
Table 7: Model 3 Controlling Students Background and SES

\begin{tabular}{|c|c|c|c|c|c|}
\hline & $\begin{array}{l}\text { African } \\
\text { Studies }\end{array}$ & CS1 & $\mathrm{CL} 1$ & $\mathrm{CS}_{2}$ & $\mathrm{CL} 2$ \\
\hline \multicolumn{6}{|c|}{ Fixed Part (Coefficient) } \\
\hline Cons/intercepts & 0.055 [0.153] & $0.070[0.138]$ & 0.237 [0.113] & $0.001[0.127]$ & $0.234[0.117]$ \\
\hline \multicolumn{6}{|l|}{ Prior attainment } \\
\hline English & $0.161[0.024]^{*}$ & $0.013[0.024]$ & $0.004[0.024]$ & $-0.019[0.023]$ & $-0.072[0.021]^{*}$ \\
\hline Maths & $0.041[0.024]$ & $-0.009[0.025]$ & $0.040[0.026]$ & $\mid-0.005[0.024]$ & $-0.030[0.022]$ \\
\hline Science & $0.081[0.025]^{*}$ & $-0.008[0.007]$ & $-0.028[0.026]$ & $-0.006[0.024]$ & $0.009[0.022]$ \\
\hline $\mathrm{CS} / \mathrm{CL}_{1}$ & & & & $0.388[0.023]^{*}$ & $0.326[0.020]^{*}$ \\
\hline \multicolumn{6}{|l|}{ Background factors } \\
\hline $\begin{array}{l}\text { Ethnic group } \\
\text { (ref: others): } \\
\text { Ga-Adamgbe }\end{array}$ & $\begin{array}{c}-0.215 \\
{[0.072]^{*}}\end{array}$ & $-0.033[0.027]$ & $-0.053[0.075]$ & $0.028[0.069]$ & $-0.055[0.064]$ \\
\hline \multicolumn{6}{|l|}{ SES } \\
\hline \begin{tabular}{|l|} 
Residence of \\
student (ref: city) \\
District capital
\end{tabular} & $0.055[0.077]$ & $0.158[0.078]^{*}$ & $-0.032[0.061]$ & $0.065[0.075]$ & 0.021 [0.051] \\
\hline Town & $-0.083[0.840]$ & $0.165[0.087]$ & $-0.054[0.069]$ & $-0.001[0.083]$ & $-0.069[0.058]$ \\
\hline Rural & $0.096[0.057]$ & $0.030[0.058]$ & $0.008[0.080]$ & \begin{tabular}{|l|}
$-0.031[0.055]$ \\
\end{tabular} & $-0.041[0.068]$ \\
\hline \multicolumn{6}{|l|}{ Random Part } \\
\hline Between Tr./Dept. & $\begin{array}{c}0.261 \\
{[0.099]^{*}}\end{array}$ & $0.192[0.075]^{*}$ & $0.110 .046]^{*}$ & $0.155[0.061]^{*}$ & 0.153 [0.059]* \\
\hline Between Students & $\begin{array}{c}0.826 \\
{[0.027]^{*}}\end{array}$ & $0.823[0.028]^{*}$ & $\begin{array}{c}0.907 \\
{[0.031]^{*}}\end{array}$ & $0.749[0.025]^{*}$ & $0.650[0.022]^{*}$ \\
\hline Total & 1.087 & 1.015 & 1.018 & 0.904 & 0.803 \\
\hline \multicolumn{6}{|c|}{ \% Variance explained } \\
\hline Tr./Dept. Level & 12 & 3 & 1 & 17 & 27 \\
\hline Student & 5 & 1 & 0 & 9 & 14 \\
\hline Total & 7 & o & 0 & 11 & 16 \\
\hline $\begin{array}{l}\text { \% Variance } \\
\text { attributable } \\
\text { to Tr./Dept. }\end{array}$ & 24 & 19 & 11 & 17 & 19 \\
\hline
\end{tabular}

Note: * = Statistically significant at .050 significance level
Table 8: Model 4 Controlling for Department Context (2009 Dataset)

\begin{tabular}{|c|c|c|c|c|c|}
\hline & African Studies & $\mathrm{CS}_{1}$ & $\mathrm{CL}_{1}$ & $\mathrm{CS}_{2}$ & $\mathrm{CL} 2$ \\
\hline \multicolumn{6}{|l|}{ Fixed Part } \\
\hline Cons/intercepts & $0.196[0.128]$ & $0.103[0.143]$ & $0.172[0.120]$ & $0.002[0.130]$ & $0.118[0.123]$ \\
\hline \multicolumn{6}{|l|}{ Prior attainment } \\
\hline English & $0.161[0.024]^{*}$ & $0.015[0.024]$ & $0.004[0.025]$ & $-0.017[0.023]$ & $-0.071[0.021]^{*}$ \\
\hline Maths & $0.035[0.0250]$ & $-0.011[0.025]$ & $0.041[0.026]$ & $-0.004[0.024]$ & $-0.030[0.022]$ \\
\hline Science & $0.080[0.025]^{*}$ & \begin{tabular}{|l|}
$-0.008[0.007]$ \\
\end{tabular} & $-0.029[0.026]$ & $-0.006[0.024]$ & $0.008[0.022]$ \\
\hline $\mathrm{CS}_{1} / \mathrm{CL}_{1}$ & & & & $0.384[0.023]^{*}$ & $0.323[0.020]^{*}$ \\
\hline \multicolumn{6}{|l|}{ Background factors } \\
\hline $\begin{array}{l}\text { Language (ref: } \\
\text { others): } \\
\text { Ga-Adamgbe }\end{array}$ & $-0.222[0.072]^{*}$ & $-0.031[0.072]$ & $-0.048[0.075]$ & $0.029[0.069]$ & $-0.054[0.064]$ \\
\hline \multicolumn{6}{|l|}{ SES } \\
\hline $\begin{array}{l}\text { Residence of } \\
\text { student } \\
\text { (ref: city) District } \\
\text { capital }\end{array}$ & $0.056[0.077]$ & $0.157[0.078] *$ & $-0.033[0.061]$ & $0.068[0.075]$ & $0.022[0.051]$ \\
\hline Town & $-0.085[0.084]$ & $0.164[0.087]$ & $-0.053[0.069]$ & $-0.001[0.083]$ & $-0.068[0.058]$ \\
\hline Rural & $0.095[0.057]$ & $0.030[0.058]$ & $0.011[0.080]$ & $-0.031[0.055]$ & $-0.040[0.068]$ \\
\hline \multicolumn{6}{|l|}{ Context } \\
\hline Mean English & $-0.487[0.240]^{*}$ & $-0.514[0.287]$ & $0.044[0.272]$ & $0.017[0.023]$ & $-0.180[0.287]$ \\
\hline Mean Maths & $1.422[0.374]^{*}$ & $0.044[0.416]$ & $-0.489[0.402]$ & $-0.004[0.024]$ & $-0.017[0.425]$ \\
\hline Mean Science & $-0.939[0.429]^{*}$ & $0.411[0.477]$ & $0.515[0.436]$ & $-0.006[0.023]$ & $0.213[0.462]$ \\
\hline Mean $\mathrm{CS}_{1} / \mathrm{CL}_{1}$ & & & & $0.384[0.023]^{*}$ & $0.517[0.266]$ \\
\hline \multicolumn{6}{|l|}{ Random Part } \\
\hline Between Dept. & $0.110[0.045]^{*}$ & $0.151[0.060]^{*}$ & $\begin{array}{c}0.097 \\
{[0.041]^{*}}\end{array}$ & $0.117[0.047]^{*}$ & $0.113[0.045]^{*}$ \\
\hline $\begin{array}{l}\text { Between } \\
\text { Students }\end{array}$ & $0.826[0.027]^{* *}$ & $0.823[0.028]^{*}$ & $0.907[0.031]^{*}$ & $0.748[0.025]^{*}$ & $0.649[0.022]^{*}$ \\
\hline Total & 0.936 & 0.974 & 1.004 & 0.865 & 0.762 \\
\hline \multicolumn{6}{|l|}{ Variance Explained } \\
\hline Dept. & 68 & 19 & 12 & 37 & 46 \\
\hline Student & 5 & 1 & o & 10 & 14 \\
\hline Total & 20 & 4 & 2 & 15 & 21 \\
\hline $\begin{array}{l}\text { \%Variance } \\
\text { attributable } \\
\text { to Dept. }\end{array}$ & 12 & 16 & 10 & 14 & 15 \\
\hline
\end{tabular}

Note: * = Statistically significant at .050 significance level 


\begin{tabular}{|c|c|c|c|c|c|c|c|c|c|c|}
\hline & & & $\begin{array}{c}\text { Model } \\
\text { TA }\end{array}$ & & & & & $\begin{array}{c}\text { Model } \\
4 \mathrm{~A}\end{array}$ & & \\
\hline & AFS & $\mathrm{CS}_{1}$ & $\mathrm{CL}_{1}$ & $\mathrm{CS}_{2}$ & $\mathrm{CL} 2$ & AFS & $\mathrm{CS}_{1}$ & $\mathrm{CL}_{1}$ & $\mathrm{CS}_{2}$ & $\mathrm{CL} 2$ \\
\hline \multicolumn{11}{|l|}{ Fixed Part } \\
\hline Cons & $\begin{array}{c}0.114 \\
{[0.134]}\end{array}$ & $\begin{array}{c}0.253 \\
{[0.174]}\end{array}$ & $\begin{array}{c}0.195 \\
{[0.164]}\end{array}$ & $\begin{array}{c}0.213 \\
{[0.147]}\end{array}$ & $\begin{array}{c}0.375 \\
{[0.213]}\end{array}$ & {$\left[\begin{array}{c}0.371 \\
{[0.169]^{*}}\end{array}\right.$} & $\begin{array}{c}0.245 \\
{[0.174]}\end{array}$ & $\begin{array}{c}0.918 \\
{[0.200]^{*}}\end{array}$ & $\begin{array}{c}0.152 \\
{[0.097]}\end{array}$ & $\begin{array}{c}0.274 \\
{[0.173]}\end{array}$ \\
\hline Slope & $\begin{array}{c}-0.047 \\
{[0.069]}\end{array}$ & $\begin{array}{c}-0.101 \\
{[0.071]}\end{array}$ & $\begin{array}{c}-0.045 \\
{[0.063]}\end{array}$ & $\begin{array}{c}-0.083 \\
{[0.056]}\end{array}$ & \begin{tabular}{|c|}
-0.121 \\
{$[0.091]$}
\end{tabular} & \begin{tabular}{|c}
-0.222 \\
{$[0.088]$}
\end{tabular} & $\begin{array}{c}-0.109 \\
{[0.071]^{*}}\end{array}$ & $\left.\begin{array}{c}0.045 \\
{[0.064]}\end{array}\right]$ & $\begin{array}{c}-0.061 \\
{[0.046]}\end{array}$ & $\begin{array}{l}-0.098 \\
{[0.075]}\end{array}$ \\
\hline \multicolumn{11}{|c|}{ Prior attainment } \\
\hline English & & & & & & $\begin{array}{c}0.056 \\
{[0.012]^{* *}}\end{array}$ & $\begin{array}{c}0.084 \\
{[0.013]^{*}}\end{array}$ & $\begin{array}{c}0.073 \\
{[0.013]^{*}}\end{array}$ & {$\left[\begin{array}{c}0.029 \\
{[0.013]^{*}}\end{array}\right.$} & \begin{tabular}{|l|}
-0.013 \\
{$[0.011]$}
\end{tabular} \\
\hline Maths & & & & & & $\mid \begin{array}{c}0.077 \\
{[0.014]^{*}}\end{array}$ & $\begin{array}{c}0.009 \\
{[0.014]}\end{array}$ & $\mid \begin{array}{c}0.034 \\
{[0.014]^{* *}}\end{array}$ & $\begin{array}{c}0.003 \\
{[0.013]}\end{array}$ & $\begin{array}{c}0.034 \\
{[0.012]}\end{array}$ \\
\hline Science & & & & & & $\begin{array}{c}0.057 \\
{[0.014]^{*}}\end{array}$ & $\begin{array}{c}0.043 \\
{[0.014]^{*}}\end{array}$ & {$\left[\begin{array}{c}0.043 \\
{[0.014]^{* *}}\end{array}\right.$} & $\begin{array}{c}0.027 \\
{[0.014]^{*}}\end{array}$ & $\begin{array}{c}0.010 \\
{[0.012]}\end{array}$ \\
\hline $\mathrm{CS}_{1} / \mathrm{CL}_{1}$ & & & & & & & & & $\begin{array}{c}0.302 \\
{[0.013]^{*}}\end{array}$ & $\begin{array}{c}0.360 \\
{[0.011]}\end{array}$ \\
\hline \multicolumn{11}{|l|}{ Background } \\
\hline Age & & & & & & $\begin{array}{c}-0.001 \\
{[0.005]}\end{array}$ & $\begin{array}{c}-0.018 \\
{[0.005]^{*}}\end{array}$ & $\begin{array}{c}-0.032 \\
{[0.005]^{*}}\end{array}$ & {$\left[\begin{array}{c}-0.012 \\
{[0.005]^{*}}\end{array}\right.$} & $\begin{array}{c}-0.013 \\
{[0.005]}\end{array}$ \\
\hline $\begin{array}{l}\text { Gender } \\
\text { (Male) }\end{array}$ & & & & & & $\mid \begin{array}{c}0.114 \\
{[0.028]^{*}}\end{array}$ & $\begin{array}{c}0.016 \\
{[0.029]}\end{array}$ & $\mid \begin{array}{c}-0.100 \\
{[0.030]^{* *}}\end{array}$ & {$\left[\begin{array}{c}0.021 \\
{[0.029]}\end{array}\right.$} & $\begin{array}{l}-0.042 \\
{[0.026]}\end{array}$ \\
\hline \begin{tabular}{|l} 
Mean \\
English
\end{tabular} & & & & & & $\begin{array}{c}-0.262 \\
{[0.119]^{*}}\end{array}$ & $\begin{array}{c}-0.325 \\
{[0.351]}\end{array}$ & $\begin{array}{c}-0.163 \\
{[0.306]}\end{array}$ & $\begin{array}{c}0.251 \\
{[0.172]}\end{array}$ & $\begin{array}{c}-0.321 \\
{[0.318]}\end{array}$ \\
\hline $\begin{array}{l}\text { Mean } \\
\text { Science }\end{array}$ & & & & & & $\begin{array}{c}-0.115 \\
{[0.324]}\end{array}$ & $\begin{array}{c}0.334 \\
{[0.209]}\end{array}$ & $\begin{array}{c}0.043 \\
{[0.014]^{*}}\end{array}$ & $\begin{array}{c}0.193 \\
{[0.102]}\end{array}$ & $\begin{array}{c}0.004 \\
{[0.189]}\end{array}$ \\
\hline \multicolumn{11}{|c|}{ Random Part (Variances) } \\
\hline \begin{tabular}{|l|} 
Between \\
Tr./Dept. \\
in their \\
intercepts \\
\end{tabular} & $\begin{array}{c}0.251 \\
{[0.102]^{* *}}\end{array}$ & $\begin{array}{c}0.447 \\
{[0.171]^{* *}}\end{array}$ & $\begin{array}{c}0.393 \\
{[0.152]^{*}}\end{array}$ & $\begin{array}{c}0.308 \\
{[0.121]^{* *}}\end{array}$ & $\begin{array}{c}0.689 \\
{[0.256]^{* *}}\end{array}$ & $\begin{array}{c}0.248 \\
{[0.100]^{*}}\end{array}$ & $\begin{array}{c}0.443 \\
{[0.171] *}\end{array}$ & $\begin{array}{c}0.386 \\
{[0.149]^{* *}}\end{array}$ & $\begin{array}{c}0.114 \\
{[0.051]^{* *}}\end{array}$ & $\begin{array}{c}0.442 \\
{[0.167]^{*}}\end{array}$ \\
\hline Slope & $\begin{array}{c}0.066 \\
{[0.027]^{* *}} \\
\end{array}$ & $\begin{array}{c}0.073 \\
{[0.029]^{*}}\end{array}$ & $\begin{array}{c}0.055 \\
{[0.022]} \\
\end{array}$ & $\begin{array}{c}0.043 \\
{[0.011]^{* *}}\end{array}$ & $\begin{array}{c}0.125 \\
{[0.047]^{* *}}\end{array}$ & $\begin{array}{c}0.069 \\
{[0.027]^{* *}}\end{array}$ & $\begin{array}{c}0.072 \\
{[0.028]^{*}}\end{array}$ & $\begin{array}{c}0.057 \\
{[0.027]^{*}}\end{array}$ & $\begin{array}{c}0.027 \\
{[0.021]} \\
\end{array}$ & $\begin{array}{c}0.084 \\
{[0.032]^{*}}\end{array}$ \\
\hline \begin{tabular}{|l|} 
Between \\
students
\end{tabular} & $\begin{array}{c}0.921 \\
{[0.017]^{*}}\end{array}$ & $\begin{array}{c}0.848 \\
{[0.016]^{*}}\end{array}$ & $\begin{array}{c}0.881 \\
{[0.016]^{*}}\end{array}$ & $\begin{array}{c}0.930 \\
{[0.017]^{*}}\end{array}$ & $\begin{array}{c}0.783 \\
{[0.014]^{*}}\end{array}$ & $\begin{array}{c}0.903 \\
{[0.017]^{* *}}\end{array}$ & $\begin{array}{c}0.836 \\
{[0.015]^{* *}}\end{array}$ & $\begin{array}{c}0.864 \\
{[0.016]^{*}}\end{array}$ & $\begin{array}{c}0.847 \\
{[0.016]^{*}}\end{array}$ & $\begin{array}{c}0.665 \\
{[0.012]^{*}}\end{array}$ \\
\hline Total & 1.172 & 1.295 & 1.274 & 1.238 & 1.472 & 1.151 & 1.279 & 1.250 & 0.978 & 1.107 \\
\hline \multicolumn{11}{|c|}{ Variance explained } \\
\hline Tr./Dept. & & & & & & 1 & 1 & 2 & 63 & 36 \\
\hline Student & & & & & & 2 & 1 & 2 & 9 & 15 \\
\hline Total & & & & & & 2 & 1 & 2 & 21 & 25 \\
\hline $\begin{array}{l}\text { \% variance } \\
\text { attributable } \\
\text { to } T r \text { r. dept. }\end{array}$ & 21 & 36 & 31 & 25 & 47 & 22 & 35 & 31 & 12 & 40 \\
\hline
\end{tabular}

Note: * = Statistically significant at .050 significance level.

\section{Is Transition from Secondary to Tertiary Education Less Likely among Black South Africans than their Non-Black Counterparts in the Democratic Dispensation?}

\author{
Nisha Sewdass and Eric O Udjo
}

Abstract

Education provides the building blocks for skills development for a country's labour market. Investment in education is hence an important determinant of economic growth and has been associated with various economic benefits. However, non-transition to tertiary education is a common phenomenon. This study examined the probability of a specified age cohort transiting to tertiary education in South Africa and compared Black South Africans with other population groups considering environmental and individual factors. Using cross-sectional data from the 2016 South African Community Survey, the study revealed that the difference in the probability of transition to tertiary education between Whites and Blacks was not statistically significant. The findings will be useful to policy makers in formulating strategies to improve the quality of the labour market, and thus South Africa's economic competitiveness.

Key words: Transition to tertiary education, South African education system, apartheid education, post-apartheid education, economic development

L'éducation est la base du développement des compétences pour le marché du travail d'un pays. L'investissement dans l'éducation est donc un déterminant important de la croissance économique et a été associé à divers avantages économiques. Toutefois, la difficulté de passage vers le niveau supérieur est un phénomène courant. Cette étude examine la probabilité qu'a une cohorte d'âge spécifiée de passer vers le niveau d'enseignement supérieur en Afrique du Sud et compare le niveau de passage des Sud-Africains noirs avec celui d'autres groupes de population en tenant compte de

ABOUT THE AUTHORS: NISHA SEWDASS, University of South Africa. Email: sewdan@ unisa.ac.za and ERIC O UDJO, University of South Africa. 